\title{
Interannual Herbaceous Biomass Response to Increasing Honey Mesquite Cover on Two Soils
}

\author{
W. Richard Teague, ${ }^{1}$ R. Jim Ansley, ${ }^{1}$ William E. Pinchak, ${ }^{1}$ Steven L. Dowhower, ${ }^{2}$ \\ Shannon A. Gerrard, ${ }^{3}$ and J. Alan Waggoner ${ }^{3}$ \\ Authors are ${ }^{1}$ Professor, ${ }^{2}$ Senior Research Associate, and ${ }^{3}$ Research Associate, Texas AgriLife Research, PO Box 1658, Vernon, TX 76385-1658, USA, and \\ Department of Ecosystem Science and Management, Texas A®M University System, College Station, TX 77843, USA.
}

\begin{abstract}
This study quantified herbaceous biomass responses to increases in honey mesquite (Prosopis glandulosa Torr.) cover on two soils from 1995 to 2001 in north central Texas. Vegetation was sampled randomly with levels of mesquite ranging from $0 \%$ to $100 \%$. With no mesquite covering the silt loam soils of bottomland sites, peak herbaceous biomass averaged $( \pm \mathrm{SE})$ $3300 \pm 210 \mathrm{~kg} \cdot \mathrm{ha}^{-1}$ vs. $2560 \pm 190 \mathrm{~kg} \cdot \mathrm{ha}^{-1}$ on clay loam soils of upland sites $(P=0.001)$. A linear decline of $14 \pm 2.5 \mathrm{~kg} \cdot \mathrm{ha}^{-1}$ in herbaceous biomass occurred for each percent increase in mesquite cover $(P=0.001)$. The slope of this decline was similar between soils $(P=0.135)$. Herbaceous biomass with increasing mesquite cover varied between years $(P=0.001)$ as did the slope of decline $(P=0.001)$. Warm-season herbaceous biomass decreased linearly with increasing mesquite cover averaging a $73 \pm 15 \%$ reduction at $100 \%$ mesquite cover $(P=0.001)$ compared to $0 \%$ mesquite cover. Coolseason herbaceous biomass was similar between soils with no mesquite, $1070 \pm 144 \mathrm{~kg} \cdot \mathrm{ha}^{-1}$ for silt loam vs. $930 \pm 140 \mathrm{~kg} \cdot \mathrm{ha}^{-1}$ for clay loam soils, but averaged $340 \pm 174 \mathrm{~kg} \cdot \mathrm{ha}^{-1}$ more on silt loam than on clay loam soils at $100 \%$ mesquite cover $(P=0.004)$. Multiple regression analysis indicated that each centimeter of precipitation received from the previous October through the current September produced herbaceous biomass of $51 \mathrm{~kg} \cdot \mathrm{ha}^{-1}$ on silt loam and $41 \mathrm{~kg} \cdot \mathrm{ha}^{-1}$ on clay loam soils. Herbaceous biomass decreased proportionally with increasing mesquite cover up to $29 \mathrm{~kg} \cdot \mathrm{ha}{ }^{-1}$ at $100 \%$ mesquite cover for each centimeter of precipitation received from January through September. Increasing mesquite cover reduces livestock forage productivity and intensifies drought effects by increasing annual herbaceous biomass variability. From a forage production perspective there is little advantage to having mesquite present.
\end{abstract}

\section{Resumen}

Este estudio cuantificó las respuestas en la biomasa de herbáceas debido a los incrementos en la cobertura de mezquite (Prosopis glandulosa Torr.) en dos tipos de suelo de 1995 a 2001 en el Norte Centro de Texas. La vegetación fue muestreada al azar, con niveles de mezquite dentro del rango de 0 a $100 \%$. En ausencia de mezquite en suelos franco-arcillosos de sitios bajos, la máxima biomasa de herbáceas promedió $3300 \pm 210$, comparada con $2560 \pm 190 \mathrm{~kg} \cdot \mathrm{ha}^{-1}$ en los suelos arcillosos de los sitios de altiplano $(\mathrm{P}=0.001)$. Se encontró una disminución lineal de $14 \pm 2.5 \mathrm{~kg} \cdot \mathrm{ha}^{-1}$ en la biomasa de herbáceas por cada punto porcentual en el aumento de la cobertura de mezquite $(\mathrm{P}=0.001)$. La pendiente de esta disminución fue similar entre tipos de suelo $(\mathrm{P}=0.135)$. La biomasa de herbáceas con el aumento en la cobertura de mezquite varió entre años $(\mathrm{P}=0.001)$ así como la pendiente disminuyó $(\mathrm{P}=0.001)$. La biomasa de herbáceas de verano disminuyó linealmente con el aumento de la cobertura del mezquite, promediando una reducción de $73 \pm 15 \%$ al $100 \%$ de cobertura de mezquite ( $\mathrm{P}=0.001$ ), comparado con el $0 \%$ de cobertura de mezquite. La biomasa de herbáceas invernales fue similar entre suelos donde no había mezquite, 1070 $\pm 144 \mathrm{~kg} \cdot \mathrm{ha}^{-1}$ para suelos francos, contra $930 \pm 140 \mathrm{~kg} \cdot \mathrm{ha}^{-1}$ para suelos arcillosos, pero promediaron $340 \pm 174 \mathrm{~kg} \cdot \mathrm{ha}^{-1}$ más en los suelos francos que en los suelos arcillosos con una cobertura de mezquite del $100 \%(\mathrm{P}=$ 0.004). El análisis de regresión múltiple indicó que por cada $\mathrm{cm}$ de precipitación que se tuvo del Octubre previo hasta el actual Septiembre se produjo una biomasa de herbáceas de $51 \mathrm{~kg} \cdot \mathrm{ha}^{-1}$ en el suelo franco y $41 \mathrm{~kg} \cdot \mathrm{ha}^{-1}$ en el suelo arcilloso. La biomasa de herbáceas disminuyó proporcionalmente con el aumento en la cobertura de mezquite hasta $29 \mathrm{~kg} \cdot \mathrm{ha}^{-1}$ al $100 \%$ de cobertura de mezquite por cada cm de lluvia recibido desde Enero hasta Septiembre. Incrementando la cobertura de mezquite se reduce la productividad de forraje para el ganado e intensifica los efectos de la sequía, incrementando la variabilidad en la biomasa de herbáceas. Desde una perspectiva de producción de forraje, hay pocas ventajas de tener la presencia de mezquite.

Key Words: competition, drought, precipitation variability, Prosopis glandulosa, savanna, species composition, woody encroachment, woody plant

Funding was provided by the E. Paul and Helen Buck Waggoner Foundation, Inc., the US Dept of Agriculture-National Research Initiative Competitive Grants Program Agricultural Systems Grants 9404256 and 98-35108-6491, and the Texas Agricultural Experiment Station under project H 8179

Correspondence: Richard Teague, Texas Agrilife Research, PO Box 1658, Vernon, TX 76385-1658, USA. Email: r-teague@tamu.edu

Manuscript received 10 October 2007; manuscript accepted 19 June 2008.

\section{INTRODUCTION}

Increased woody plant abundance in grasslands and savannas over the past century has been widely documented (Archer et al. 2001). This widespread invasion and increase of woody species has resulted in a decline in biodiversity (West 1993; Knopf 1994), a reduction in ecosystem resilience (Peterson et 
al. 1998), and a greater likelihood of irreversible changes in plant species composition (Westoby et al. 1989) and has consequences for land-surface-atmospheric interactions (Archer et al. 2001). In the southwestern United States, mesquite (honey mesquite [Prosopis glandulosa Torr.]) is the primary encroaching woody plant species in many rangeland ecosystems. Unchecked, mesquite encroachment progresses to form closed-canopy woodlands, which significantly reduce herbaceous productivity (Bedunah and Sosebee 1984; Archer 1995; Ansley et al. 2001, 2004), threatening the sustainability of livestock ranching (Hamilton and Ueckert 2004) as well as wildlife habitat (Rollins and Cearley 2004) and grassland birds (Knopf 1994).

A number of factors including climate, soils, and disturbance regimes determine the abundance and composition of trees and shrubs and the influence they have on herbaceous composition and biomass in dry ecosystems (Walker 1987; Scholes and Archer 1997). Woody plant-grass relations are strongly influenced by soil. These integrated interactions need to be quantified to determine the production (Brock et al. 1978; McDaniel et al. 1982; Scifres and Hamilton 1993; Andales et al. 2006), environmental (West 1993; Knopf 1994; Peterson et al. 1998; Archer et al. 2001), and economic consequences (Vantassell and Conner 1986; Teague et al. 2001) of different land management options that are designed to manage woody plants. The interannual variability in precipitation and resulting variability of productivity on semiarid rangeland ecosystems is proportionally greater than that of more mesic ecosystems in the North American Great Plains (Knapp and Smith 2001). This makes development of effective management strategies difficult and complex. Simulation models have great potential as research tools and decision aids for natural resource managers by collating results from experiments in different fields or locations within the context of a more encompassing systems management framework that treats the ranch business as a complete bio-economic unit (Andales et al. 2006; Teague et al. 2008). Such models require essential biological data under realistic management settings to perform adequately. The field research reported in this paper provides data on the competitive effects of mesquite on herbaceous biomass for use in building models to assess the relative merits of different strategic and tactical land management options.

Published research on herbaceous biomass and composition response to increasing mesquite has documented short-term measurements ( $2 \mathrm{yr}$ to $3 \mathrm{yr}$ ) immediately following mesquite removal with few intermediate levels of mesquite canopy cover evaluated (Scifres and Polk 1974; Scifres et al. 1977; Dahl et al. 1978; Bedunah and Sosebee 1984; Heitschmidt and Dowhower 1991; Warren et al. 1996), or long-term discontinuous measurements ( $10 \mathrm{yr}$ to $20 \mathrm{yr}$ ) from a single soil type (Ansley et al. 2004). Few of these studies have evaluated herbaceous biomass responses over the range of variability of precipitation, the full range from no mesquite to $100 \%$ mesquite canopy cover, and different soil types experienced in these semiarid ecosystems.

The goal of this study was to examine the influence of increasing levels of mesquite cover $(0 \%$ to $100 \%)$ on two soil types under a wide variation of annual and interannual precipitation on total herbaceous plant biomass and the relative biomass of warm- and cool-season herbaceous plant functional groups. The study was conducted from 1995 to 2001. The two soils chosen for the study are both associated with high levels of mesquite, occur widely through the region, and support different levels of herbaceous biomass (US Department of Agriculture Soil Conservation Service 1969; Teague et al. 2004). We also measured responses under a ranch-scale management scenario that included livestock grazing. We required an integrated herbaceous and livestock response to increasing mesquite cover under realistic grazing conditions to parameterize a simulation model we used to further explore whole-ranch system responses to different grazing and burning interventions (Teague et al. 2008). As a separately published part of this study (Ansley et al. 2004) we have reported the response of herbaceous plants to increasing mesquite in grazing exclosures on one soil type. A unique feature of this region is that there is codominance of warm-season and cool-season herbaceous midgrasses that results from significant precipitation received in both warm and cool seasons (Heitschmidt et al. 1982).

\section{METHODS}

The investigation was conducted in north-central Texas on the 14170-ha Waggoner Experimental Ranch (lat $33^{\circ} 50^{\prime} \mathrm{N}$, long $\left.99^{\circ} 5^{\prime} \mathrm{W}\right)$ near Vernon. Elevation ranges from $335 \mathrm{~m}$ to $396 \mathrm{~m}$. The climate is continental with an average of 220 frost-free growing days. Mean annual precipitation is $648 \mathrm{~mm}$ (range: $490 \mathrm{~mm}$ to $1000 \mathrm{~mm}$ ), which is bimodally distributed with peaks in May $(95 \mathrm{~mm})$ and September $(76 \mathrm{~mm})$, though significant precipitation can be expected in any month. Mean monthly temperature varies from $3.9^{\circ} \mathrm{C}$ in January to $36.4^{\circ} \mathrm{C}$ in July.

The woody vegetation consists of mesquite with some lotebush (Ziziphus obtusifolia [Hook. ex. Torr. \& A. Gray] A. Gray). Succulents represented by Opuntia spp. are common. The herbaceous vegetation was dominated by a cool-season perennial, Texas wintergrass (Nassella leucotricha Trin. \& Rupr.); warm-season perennials silver bluestem (Bothriochloa laguroides DC.), sideoats grama (Bouteloua curtipendula [Michx.] Torr.), meadow dropseed (Sporobolus compositus [Poir.] Merr.), buffalograss (Buchloe dactyloides [Nutt.] Engelm.); the cool-season annual Japanese brome grass (Bromus japonicus Thunb. ex Murray); and the warm-season forbs western ragweed (Ambrosia psilostachya DC.), annual broomweed (Gutierrezia texana [DC.] Torr. \& A. Gray), and heath aster (Aster ericoides L.). Nomenclature follows Diggs et al. (1999).

Measurements were made on eight landscape-scale replicates ranging in size from 1283 ha to 2130 ha. Equivalent stocking rates of commercial beef cattle in a cow-calf enterprise were used on all replicates prior to and throughout this study and cows and calves grazed on the pastures all year. Stocking rate was initially set at $7.5 \mathrm{ha} \cdot$ animal unit $\mathrm{yr}^{-1}$ in 1995 based on Natural Resources Conservation Service recommendations. Rates were reduced to $11 \mathrm{ha} \cdot \mathrm{cow}^{-1}$ in 1996 and $14 \mathrm{ha} \cdot \mathrm{cow}^{-1}$ by 2001 following several droughts. No part of this study was impacted by fire.

The study was conducted on two dominant soil types (silt loam bottomland and upland clay loam flats) that represent different ecological sites (Table 1). 
Table 1. Summary of soil characteristics from US Department of Agriculture Soil Conservation Service (1969) for dominant soils with significant mesquite populations on the Waggoner Experimental Ranch in Wilbarger County, Texas.

\begin{tabular}{lll}
\hline \multicolumn{1}{c}{ Parameter } & \multicolumn{1}{c}{ Clay loam } & \multicolumn{1}{c}{ Silt loam } \\
\hline Catenal Position & Summit & Footslope \\
Permeability & Slow, subject to crusting & Moderate, well drained \\
Soil series & Tillman & Wheatwood \\
Hydrology & Run-off & Run-on \\
Slope (\%) & $1-5$ & $1-3$ \\
Ecological site & Clay loam & Loamy bottomland \\
Site identification no. & R0 78 CY096 TX & R0 78CY103 TX \\
Taxonomic class & Fine, mixed, superactive, & Fine-silty, mixed, active, \\
& thermic Typic Paleustoll & thermic Fluventic Haplustept \\
\hline
\end{tabular}

\section{Measurements}

Herbaceous standing biomass and woody plant cover (all species) were monitored on each soil type in March, July, and November from 1995 to 2001 in all eight pasture replicates to include spring-, summer-, and fall-aspect plants that occur in this region. In each replicate, sampling was conducted along four separate 1000 -m-long transects randomly placed on each of the two soil types. Along each transect line, 20 sample points were located approximately every $50 \mathrm{~m}$. Each of these points represents one of seven possible mesquite cover levels with associated herbaceous vegetation. Sample points on each sampling date were located randomly and different points were sampled at each date. All sample areas were exposed to light-to-moderate livestock grazing. The assessment of the effect of mesquite on vegetation depended on an estimate of mesquite cover and herbaceous biomass at each sampling point (quadrat). The center of each quadrat was the sampling point used to estimate woody plant cover. Herbaceous biomass and mesquite cover were then calculated for each soil and pasture, for analysis by year.

To estimate herbaceous biomass associated with different levels of mesquite cover we determined peak herbaceous standing biomass in summer or fall within each soil type and pasture, resulting in 720 total sample points. The peak standing biomass occurred in either late summer or fall and was variable for different species and in different years. We used the highest (peak) standing biomass in every case to estimate the level of mesquite cover on herbaceous biomass. To simplify interpretation we report herbaceous biomass in two functional groups: warm-season or cool-season herbaceous plants (i.e., grasses or forbs). Both functional groups included annual and perennial species. The predominant species comprising these functional groups are appended (Appendix 1).

Peak herbaceous biomass estimates were based on aboveground standing biomass along these transects, using the dryweight-rank method of t'Mannetje and Haydock (1963) as modified by Jones and Hargreaves (1979). At each sample point we ranked (by standing biomass) the top three grass and top three forb species separately in each $0.05-\mathrm{m}^{2}(20 \times 25 \mathrm{~cm})$ quadrat. Visual estimates of standing (live + dead) herbaceous biomass $\left(\mathrm{g} \cdot \mathrm{m}^{-2}\right)$ by grass and forb were made before the quadrat was clipped for drying and weighing as outlined by Dowhower et al. (2001). All 20 quadrats were harvested for each $1000-\mathrm{m}$ transect and were combined to yield a total transect dry weight by grass and forb. Visually estimated species standing biomass from the 20 quadrats was then corrected using total clipped vs. total estimated grass and forb biomass to give species live and dead biomass estimates per quadrat.

Woody species have a discontinuous influence on their immediate vicinity and beyond (Belsky et al. 1989, 1993; McPherson and Wright 1990; Belsky 1992; Virginia et al. 1992; Owens et al. 1995; Dahlgren et al. 1997; Laxson et al. 1997). Most sampling methods record mean values over the area being sampled, not accounting for information at the scale of pattern created by individual woody plants, which is of prime importance in this study. To overcome this shortcoming we use a sampling technique developed by Dowhower et al. (2007) to assess woody plant influence at a single point or herbaceous vegetation sample unit. At each sampling point four quarters were established as for the point-centered quarter method of Cottam and Curtis (1956). Woody plant cover was estimated at each herbaceous sampling point on a scale of 0-2 in each of the four quarters. If height of woody plants within each quarter was less than $45^{\circ}$ vertically from the sample point, woody cover was considered to be minimal and was assigned a score of 0 . Otherwise, if the woody cover partially filled the quarter with an angle of $45^{\circ}$ to $75^{\circ}$ vertically from the sample point, a score of 1 was assigned. A score of 2 was assigned if the height of woody plants was $>75^{\circ}$ vertically from the sample point. Summing of the values for all four quarters provided a score of $0-8$, with each rank approximating $12.5 \%$ cover. Thus, a score of 8 equaled $100 \%$ woody plant cover. Comparison of scoring on 22 areas of mesquite cover measured using this method with the line-intercept method of Canfield (1941) provided regression coefficients $\left(R^{2}\right)$ of 0.96 (Dowhower et al. 2007).

In order to examine the effects of precipitation amount on herbaceous response to different levels of mesquite cover we analyzed annual precipitation (January through December), warm growing season precipitation (January through October), offset annual precipitation (October through September the following year), and cool growing season precipitation (October through June).

\section{Statistical Analyses}

Analyses of covariance of mesquite effects was a comparative experiment with mesquite cover levels associated with random herbaceous sampling locations. Results are associative rather than causal. We tested to determine if a curvilinear fit would be a significant improvement compared to a linear regression fit over the full range of mesquite cover levels. The two-stage concept of the Laird-Ware model was employed where a particular class of models is applied to different groups or treatments (Schabenberger and Pierce 2001, p. 414-418; S. Duke, personal communication, June 2006). In our case the following regression model is applied between two soils over $7 \mathrm{yr}$ : biomass $=$ intercept $+\mathrm{B} \times$ mesquite + error. Percentage of mesquite cover was used as a discrete covariate and soil and year were classification variables. Solutions were estimated indicating the impact of mesquite (slope) on herbaceous biomass per functional group for the two soils and $7 \mathrm{yr}$ 
(intercepts; PROC MIXED; SAS 2003). Homogeneity of slopes was tested for mesquite-within-soil and mesquite-within-year. Compound symmetry covariance structure was used. Year was indicated as a repeated measure and random portions were identified as soil within pasture and soil $\times$ year within pasture (Schabenberger and Pierce 2001).

Differences in biomass occurred among years and between soils within years as well as the rate of decrease of herbage with increasing mesquite between years. These differences were expected to be strongly associated with the yearly and seasonal differences in precipitation. Multiple regressions using precipitation periods and precipitation periods $\times$ mesquite and soils were conducted to arrive at a simple dynamic model that would pertain to herbaceous biomass within this range of observed conditions. Use of no-intercept regressions caused precipitation to account for all herbaceous biomass variation within the model varying by year. Seasonal precipitation was averaged at 3-mo intervals: October through December, January through March, April through June, and July through September. Factors were dropped when nonsignificant and like factors were combined when similar. Multiple regression models were compared to the model used in the Mixed Procedure using GLM type 1 sum of squares to check the relative fit to the data (SAS 2003).

\section{RESULTS}

\section{Climatic Conditions and Herbaceous Dynamics}

Precipitation (Fig. 1) and herbage dynamics varied markedly over the study period of 1995 to 2001. Annual totals for the $7 \mathrm{yr}$ ranged from $480 \mathrm{~mm}$ to $914 \mathrm{~mm}$. The dry summers and/or wet winters experienced in four of the seven experimental years (1996, 1998, 2000, and 2001) had a major impact resulting in a 2.5 -fold difference in herbaceous biomass among years.

\section{Interactive Effects of Mesquite Cover, Soil, and Year on Herbaceous Biomass}

Peak Total Herbaceous Biomass. Mesquite cover (M) had a significant effect on peak total herbaceous biomass as did the year-to-year variation $(\mathrm{Y})$ and soil $(\mathrm{S}$; Table 2$)$. There was a significant interaction between $\mathrm{M}$ and $\mathrm{Y}$ for total herbaceous biomass $(\mathrm{M} \times \mathrm{Y})$ and warm-season herbaceous biomass and for the $\mathrm{M} \times \mathrm{S}$ interaction for warm-season herbaceous biomass, indicating the influence of increasing mesquite cover on herbaceous biomass decreased more sharply when peak herbaceous biomass was greater. However, this interaction was small relative to main effects of $\mathrm{M}$, $\mathrm{Y}$, and $\mathrm{S}$ (Table 2).

Peak total herbaceous biomass changed significantly each year in response to differences in annual precipitation ( $\mathrm{Y}$; Table 2). Silt loams were more productive, averaging $3300 \mathrm{~kg} \cdot \mathrm{ha}^{-1}$ vs. $2560 \mathrm{~kg} \cdot \mathrm{ha}^{-1}$ for clay loam soils (S; Table 2) but the decrease of biomass with an increase in mesquite from $0 \%$ to $100 \%$ was similar for both soils, averaging $1410 \mathrm{~kg} \cdot \mathrm{ha}^{-1}(\mathrm{M} \times \mathrm{S}$; Table 2). Tests for curvilinear fit were not significantly different from the linear regressions presented $(P=0.90)$.

Precipitation from the previous October through September of the current year varied from approximately $400 \mathrm{~mm}$ to
$1000 \mathrm{~mm}$ over the 7-yr experimental period. As precipitation increased above $400 \mathrm{~mm}$, herbaceous biomass in response to increasing annual precipitation cover increased sharply until approximately $600 \mathrm{~mm}$, after which relatively small gains were measured with additional precipitation (Figs. 2a and 2b). Biomass on silt loam soils was approximately $700 \mathrm{~kg} \cdot \mathrm{ha}^{-1}$ higher than on clay loam soils but overall response to increasing mesquite and increasing annual precipitation was otherwise very similar (cf. Figs. $2 \mathrm{a}$ and $2 \mathrm{~b}$ ).

Although total herbaceous biomass was consistently higher on silt loam than on clay loam soils it was not significantly different between the two soils in $1999(P=0.42)$ and 2000 $(P=0.134$; Fig. 3$)$. In each year the slope of the decline of total herbaceous biomass with increasing mesquite cover was almost identical on the two soils. In contrast, slopes of the regressions for each year in response to increasing mesquite cover differed with drier years having flatter slopes (Fig. 3).

Peak Warm-Season Herbaceous Biomass. Warm-season herbaceous biomass was influenced strongly by mesquite cover (M; Table 2; Fig. 4) and was different each year $(\mathrm{M} \times \mathrm{Y}$; Table 2). Tests for curvilinear fit were not significantly different from the linear regressions presented $(P=0.38)$. Differences occurred between soils, with silt loam soils being more productive, averaging $2350 \mathrm{~kg} \cdot \mathrm{ha}^{-1}$ vs. 1730 $\mathrm{kg} \cdot \mathrm{ha}^{-1}$ for clay loam soils (Table 2). The slope of the decline in herbaceous biomass between the two soils with increasing mesquite cover was not parallel but proportional to biomass within any one year with herbaceous biomass decreasing an average of $1710 \mathrm{~kg} \cdot \mathrm{ha}^{-1}$ on silt loam vs. $1270 \mathrm{~kg} \cdot \mathrm{ha}^{-1}$ for clay loam soils $(\mathrm{M} \times \mathrm{S}$; Table 2). Slopes of the regressions differed each year in response to differing amounts of summer rainfall (Fig. 4).

Peak Cool-Season Herbaceous Biomass. Cool-season plants produced considerably less biomass than the warm-season plants (compare Figs. 4 and 5). The response to increasing mesquite cover did differ between years $(\mathrm{M} \times \mathrm{Y}$; Table 2; Fig. 5) but this effect was weak compared to the response of warm-season plants. In both 1995 and 2000 cool-season plant biomass increased marginally with increasing mesquite cover $(P \leq 0.09$; Fig. 5$)$. An examination of Figures 3,4 , and 5 illustrates that biomass had only $1 \mathrm{yr}$ each (1996 for total and 1999 for cool-season) where the $\mathrm{M} \times \mathrm{S}$ interaction was significant. In contrast, the warm-season biomass had $4 \mathrm{yr}$ (1996, 1997, 1998, and 2001) where the $\mathrm{M} \times \mathrm{S}$ interaction was significant.

With no mesquite cover, differences in standing cool-season biomass due to soils were marginal, with silt loam soils averaging $1070 \mathrm{~kg} \cdot \mathrm{ha}^{-1}$ vs. $930 \mathrm{~kg} \cdot \mathrm{ha}^{-1}$ for clay loam soils (S; Table 2). With higher levels of mesquite cover $(90 \%$ to $100 \%$ ) cool-season herbaceous plants were more productive on silt loams with $1210 \mathrm{~kg} \cdot \mathrm{ha}^{-1}$ compared to $870 \mathrm{~kg} \cdot \mathrm{ha}^{-1}$ on clay loam soils.

Regression Models Incorporating Precipitation. Best models indicated that adding precipitation from the previous year's October through December period to the current year's January through September period improved the current year's peak total herbage estimate. Using a 12-mo period beginning in September or November was inferior. 

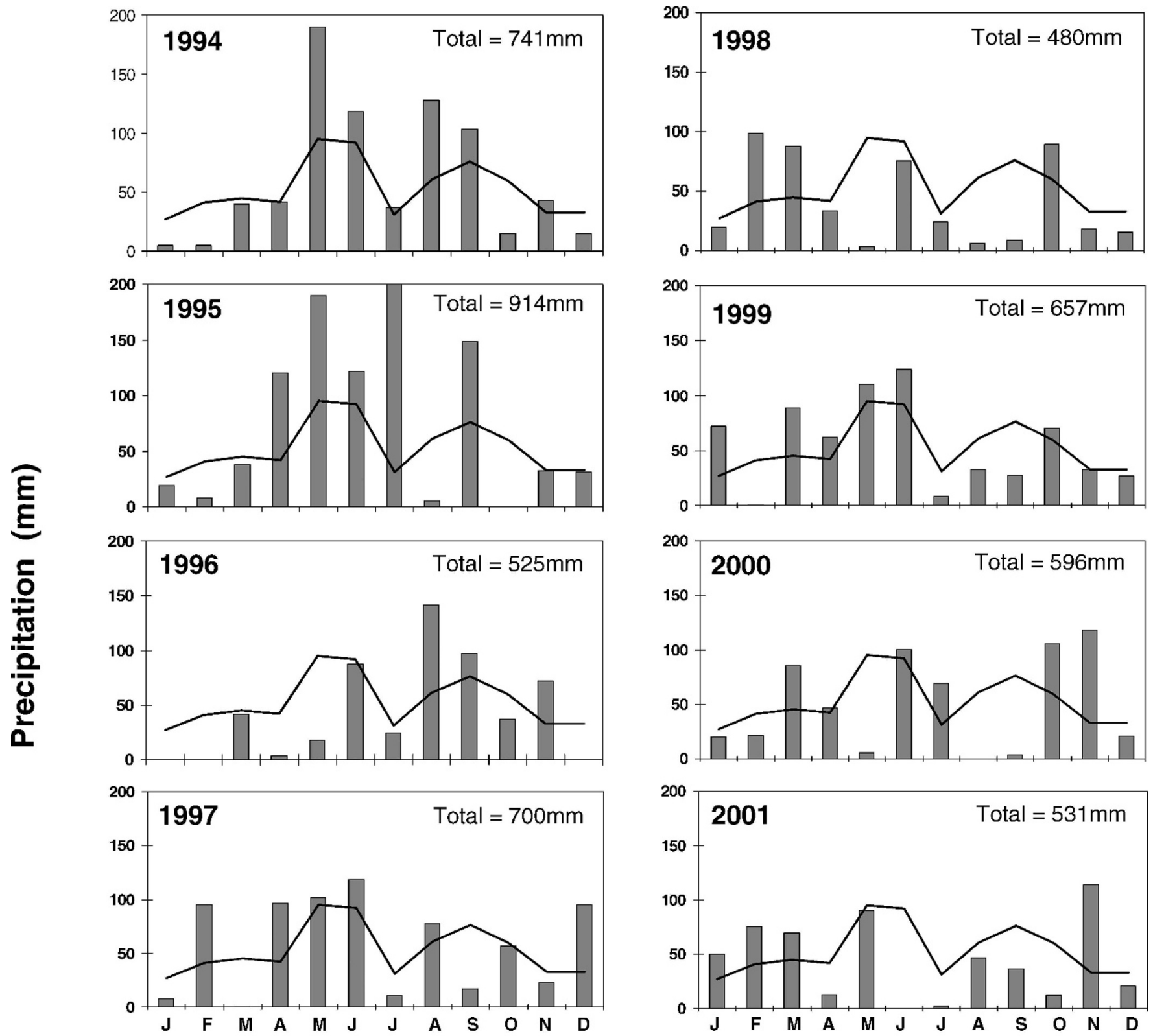

\section{Month}

Figure 1. Monthly precipitation ( $\square$ ) relative to the long-term mean monthly precipitation ( $\longrightarrow$ ) for the Waggoner Experimental Ranch in northcentral Texas from 1994 to 2001. Long-term mean annual rainfall $=648 \mathrm{~mm}$.

Best precipitation-based regression estimates of peak standing crop $\left(\mathrm{kg} \cdot \mathrm{ha}^{-1}\right)$ were as follows:

Total herbaceous plants $=30\left[\mathrm{ppt}_{\text {October }- \text { December }}+\right.$ July - September $]$

$+51\left[\mathrm{ppt}_{\text {January-June }}\right]-29\left[\mathrm{ppt}_{\text {January-September }}\right]$ mesquite

$+10\left[\mathrm{ppt}_{\text {October-January }- \text { September }}\right]$ silt loam soil

$\left[R^{2}=0.9203 ; P<0.0001\right]$
Warm - season herbaceous plants $=40\left[\mathrm{ppt}_{\text {January }- \text { June }}\right]$

$+27\left[\mathrm{ppt}_{\text {July-September }}\right]-26\left[\mathrm{ppt}_{\text {January-September }}\right]$ mesquite

$+13\left[\mathrm{ppt}_{\text {January-September }}\right]$ silt loam soil

$-11\left[\mathrm{ppt}_{\text {January }- \text { September }}\right]$ mesquite $\times$ silt loam soil

$\left[R^{2}=0.8406 ; P<0.0001\right]$ 
Table 2. Mixed model testing effect of mesquite cover (M), soil (S), and year $(Y)$ on total, warm-season, and cool-season herbaceous biomass in 1995-2001 on silt loam and clay loam soils on the Waggoner Experimental Ranch, Wilbarger County, Texas.

\begin{tabular}{llrrrr}
\hline \multirow{5}{*}{ Parameter } & Source & df & \multicolumn{1}{c}{ df } & \multicolumn{1}{c}{$F$} & $P>F$ \\
\hline Total herb & $\mathrm{M}$ & 1 & 605 & 276.02 & 0.0001 \\
& $\mathrm{M} \times \mathrm{S}$ & 1 & 605 & 2.24 & 0.1346 \\
& $\mathrm{M} \times \mathrm{Y}$ & 6 & 605 & 12.17 & 0.0001 \\
& $\mathrm{~S}$ & 1 & 14 & 36.25 & 0.0001 \\
& $\mathrm{Y}$ & 6 & 79 & 79.97 & 0.0001 \\
Warm season & $\mathrm{S} \times \mathrm{Y}$ & 6 & 79 & 2.89 & 0.0135 \\
& $\mathrm{M}$ & 1 & 605 & 328.78 & 0.0001 \\
& $\mathrm{M} \times \mathrm{S}$ & 1 & 605 & 9.88 & 0.0018 \\
& $\mathrm{M} \times \mathrm{Y}$ & 6 & 605 & 8.64 & 0.0001 \\
& $\mathrm{~S}$ & 1 & 14 & 27.34 & 0.0001 \\
& $\mathrm{Y}$ & 6 & 79 & 45.48 & 0.0001 \\
& $\mathrm{~S} \times \mathrm{Y}$ & 6 & 79 & 1.92 & 0.0874 \\
& $\mathrm{M}$ & 1 & 605 & 0.38 & 0.5386 \\
& $\mathrm{M} \times \mathrm{S}$ & 1 & 605 & 2.45 & 0.1181 \\
& $\mathrm{M} \times \mathrm{Y}$ & 6 & 605 & 3.24 & 0.0038 \\
& $\mathrm{~S}$ & 1 & 14 & 3.66 & 0.0766 \\
& $\mathrm{Y}$ & 6 & 79 & 20.32 & 0.0001 \\
& $\mathrm{~S} \times \mathrm{Y}$ & 6 & 79 & 1.21 & 0.3091 \\
\hline
\end{tabular}

Cool - season herbaceous plants $=32\left[\mathrm{ppt}_{\text {October }- \text { December }}\right]$

$+15\left[\mathrm{ppt}_{\text {January }- \text { June }}\right]-3\left[\mathrm{ppt}_{\text {October-January }- \text { June }}\right]$ mesquite

$+9\left[\mathrm{ppt}_{\text {October-January-June }}\right]$ silt loam soil

$\left[R^{2}=0.8178 ; P<0.0001\right]$

where $\mathrm{ppt}=$ precipitation for noted period $(\mathrm{cm})$ and mesquite $=$ mesquite cover percentage. For clay loam soil the silt loam soil multiplier is zero.

The precipitation based regression models $(n=720)$ accounted for all but $2-3 \%$ variation of the covariable models. Significant differences for the variable $\mathrm{Y}$ still occurred but $F$ values with precipitation regressions were reduced $92 \%$ for total and $85 \%$ for warm-season herbaceous plants compared to the covariable model. Including precipitation from the previous fall improved model $R^{2}$ values. Regressions using annual precipitation of January through December of the current year indicated lower model $R^{2}$ values of 0.90 for total, 0.81 for warm-season, and 0.76 for cool-season herbaceous plants. $F$ values remaining for the variable year were reduced from 0 $70 \%$ of covariable model $F$ values. Other effects and covariables were significant as well.

The precipitation-driven model indicated that each centimeter of precipitation produced $41 \mathrm{~kg} \cdot \mathrm{ha}^{-1}$ of total herbaceous plants on clay loam soils in open areas free of mesquite influence. Silt loams were $24 \%$ more productive than clay loam soils for total herbaceous plants and $36 \%$ more for warm-season herbaceous plants. Mesquite reduced herbaceous biomass for precipitation received from January through September. Full ( $90 \%$ to $100 \%$ ) mesquite cover reduced warm-season herbaceous plants by $75 \%$. However, full mesquite cover increased a)

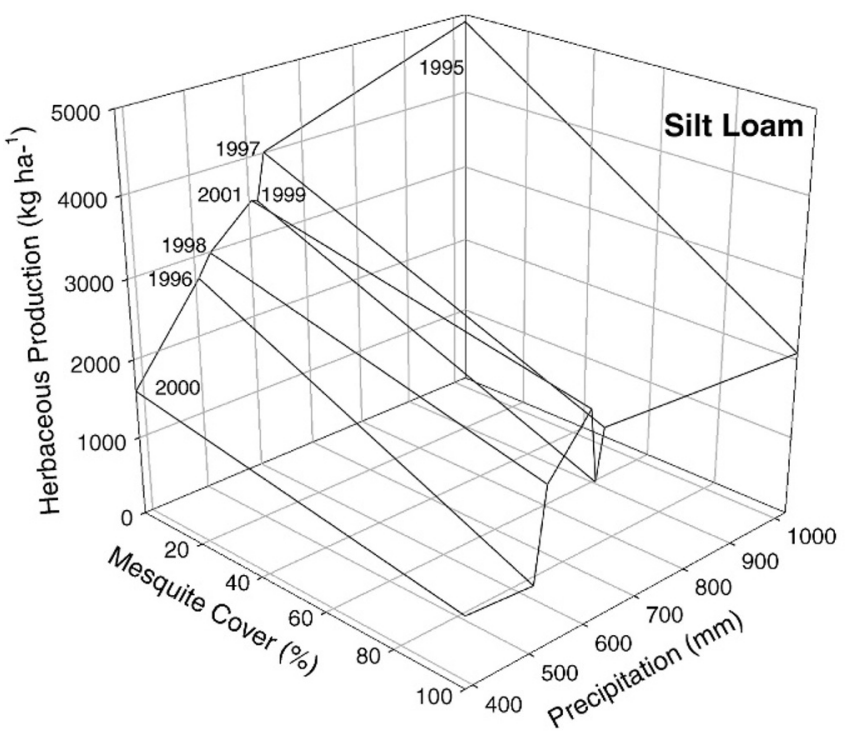

b)

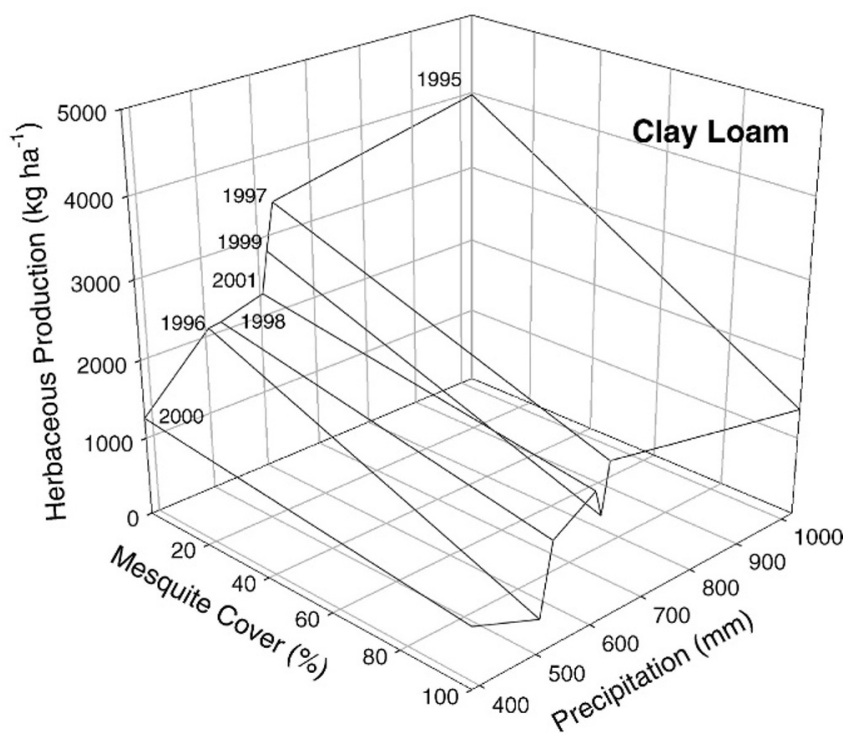

Figure 2. Regressions of total herbaceous biomass $\left(\mathrm{kg} \cdot \mathrm{ha}^{-1}\right)$ in response to rainfall from October through September for 1995-2000 and different levels of mesquite cover (\%) on $\mathbf{a}$, silt loam and $\mathbf{b}$, clay loam soils on the Waggoner Experimental Ranch in north-central Texas.

cool-season herbaceous plants on silt loams by $30 \%$. Based on average precipitation, full mesquite cover reduced total herbaceous biomass $45 \%$ on silt loams and $56 \%$ on clay loam soils.

\section{DISCUSSION}

These data were collected over a series of years that had a wide range in total precipitation and provide a broader understanding of herbaceous biomass response to woody cover compared to studies that typically are only conducted over $2 \mathrm{yr}$ or $3 \mathrm{yr}$. This study illustrates the strong effect of variable seasonality and amount of precipitation on the relative productivity of warm- and cool-season herbaceous vegetation in response to increases in mesquite cover and soil type. It also illustrates the strong carryover effect of conditions in one year to the next that can become additive over years. 

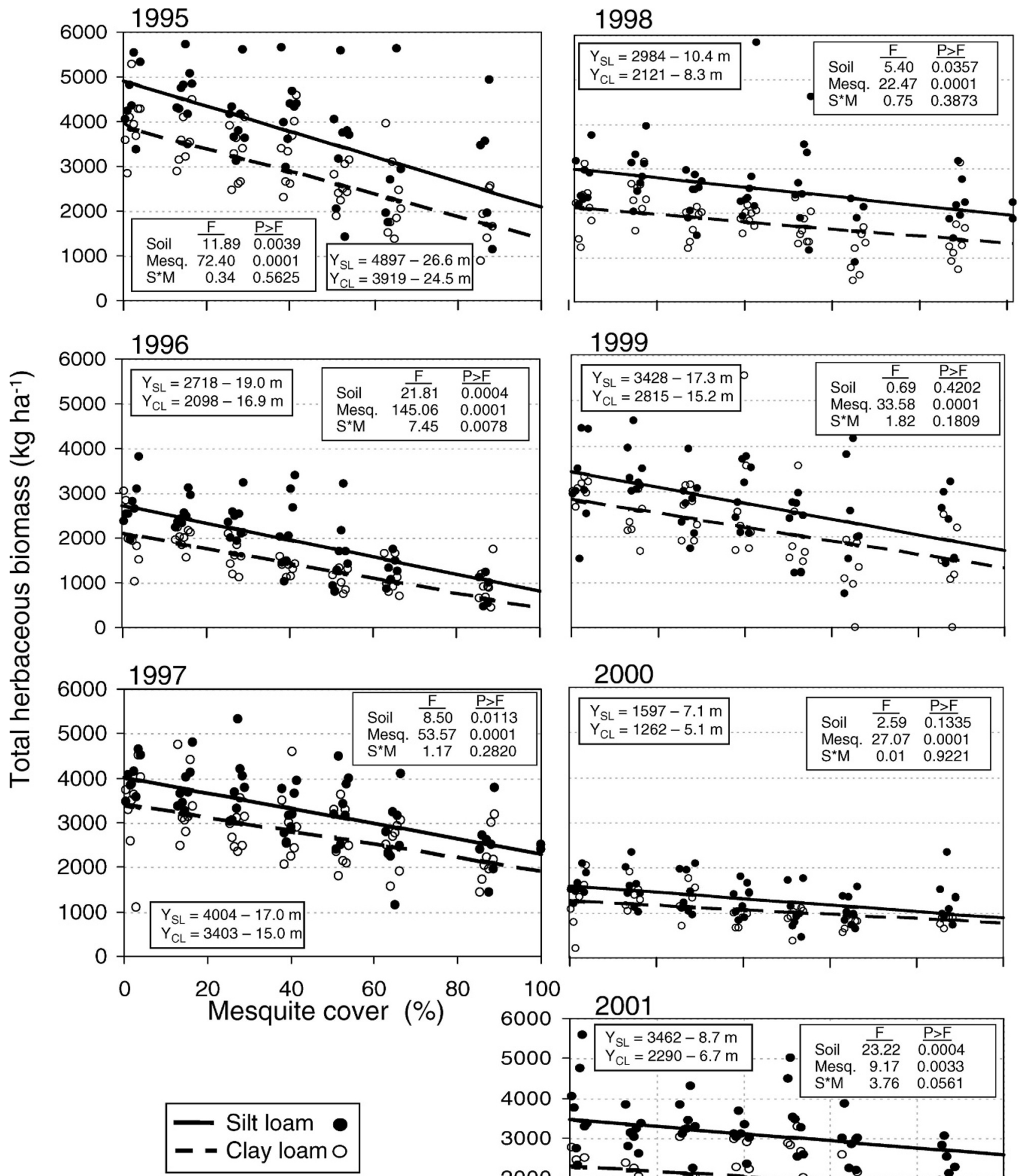

$60 \quad 100$

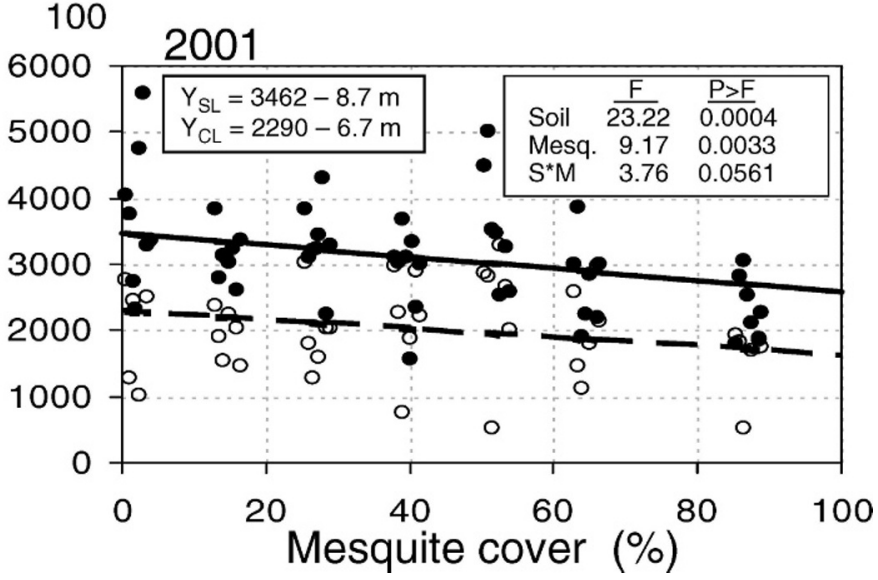

Figure 3. Regressions of total herbaceous biomass $\left(\mathrm{kg} \cdot \mathrm{ha}^{-1}\right)$ in response to different levels of mesquite cover for the calendar years $1995-2001$ on silt loam (SL) and clay loam (CL) soils on the Waggoner Experimental Ranch in north-central Texas. 


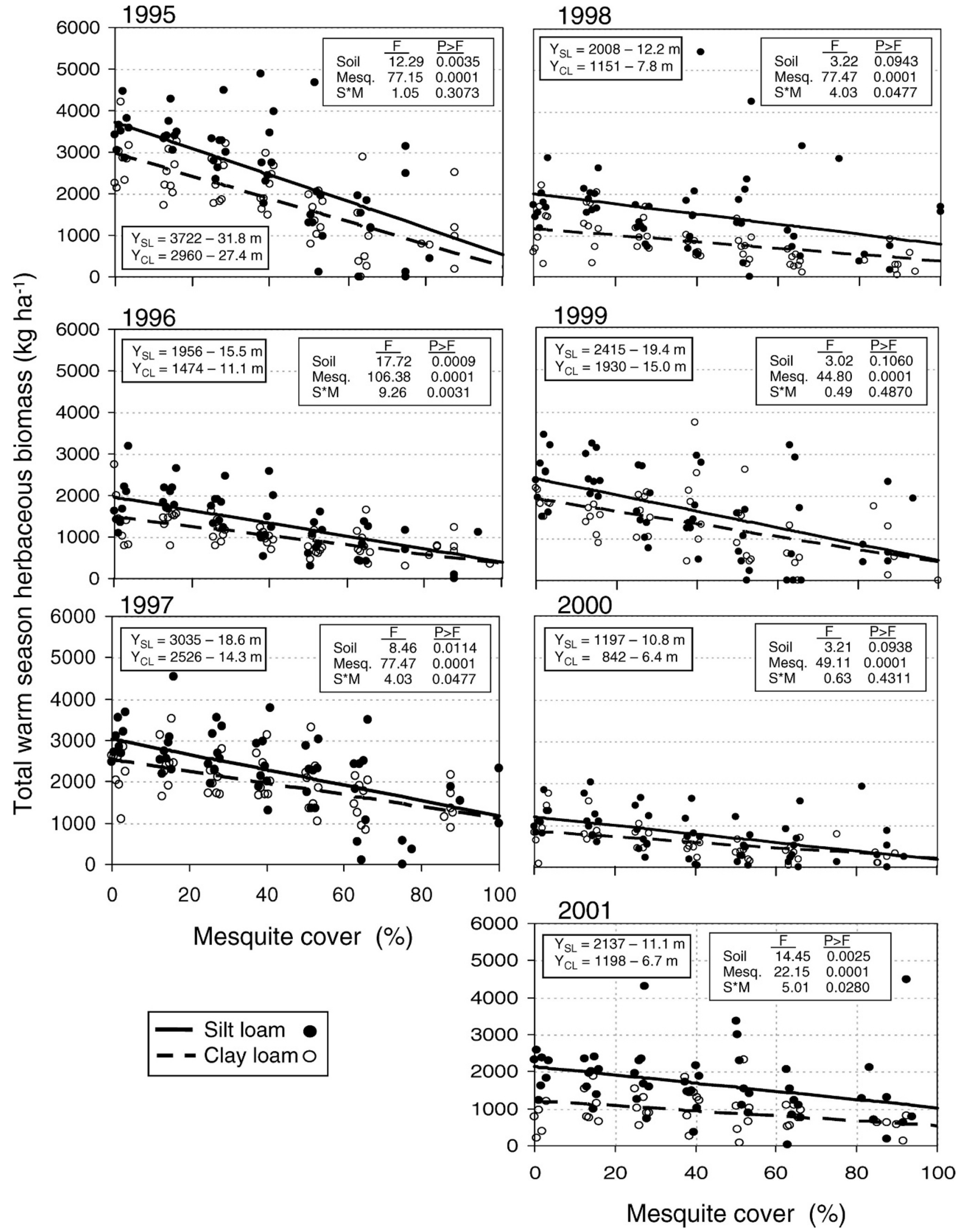

Figure 4. Regressions of total warm-season herbaceous biomass $\left(\mathrm{kg} \cdot \mathrm{ha}^{-1}\right)$ in response to different levels of mesquite cover for the calendar years 1995-2001 on silt loam (SL) and clay loam (CL) soils on the Waggoner Experimental Ranch in north-central Texas. 


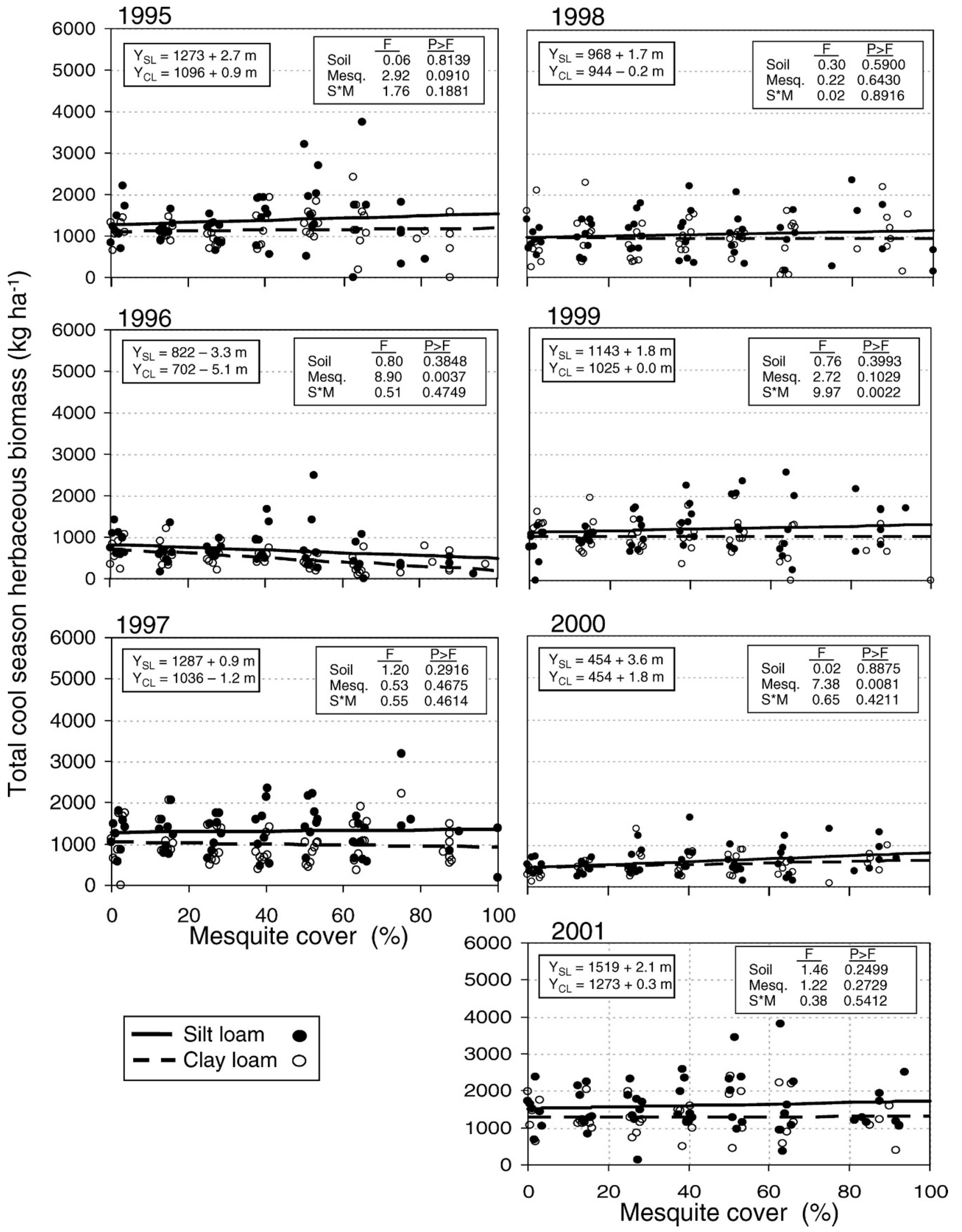

Figure 5. Regressions of total cool-season herbaceous biomass $\left(\mathrm{kg} \cdot \mathrm{ha}^{-1}\right)$ in response to different levels of mesquite cover for the calendar years 1995-2001 on silt loam (SL) and clay loam (CL) soils on the Waggoner Experimental Ranch in north-central Texas. 
Increasing mesquite cover had a dominant effect on herbaceous biomass and the relative contribution of warmand cool-season species to total herbaceous biomass, reducing total peak herbaceous standing crop $50 \%$ on average. Total herbaceous biomass was correlated best with precipitation from the previous October through September of the following year. Warm-season herbage biomass was most correlated with January through September precipitation. Cool-season herbage, which was less affected by mesquite cover, was most correlated with October through June precipitation.

Our data are comparable to predictions of herbaceous biomass levels of published data from the Great Plains. Sala et al. (1988) developed a simple predictive model based on 9548 sites throughout the Central Grassland region of the United States that estimated annual net primary production of $60 \mathrm{~kg} \cdot \mathrm{ha}^{-1}$ for each centimeter of precipitation. This compares to $51 \mathrm{~kg} \cdot \mathrm{ha}^{-1}$ predicted for silt loam and $41 \mathrm{~kg} \cdot \mathrm{ha}^{-1}$ for clay loam soils per centimeter of precipitation estimated by our model with no mesquite cover. Our model compares favorably considering our estimates were based on summer or fall peak standing crop while under moderate grazing by livestock. The difference in peak standing crop between our two soils would be expected because the silt loam soil occurred on bottomland sites subject to receiving runoff and were likely sub-irrigated whereas clay loam soils occurred on flat expanses of $1-5 \%$ slopes that receive no net runoff.

Regarding reductions in herbaceous biomass with increasing mesquite cover, our results are comparable to other results from this ecoregion. Scifres and Polk (1974) measured a $3 \mathrm{~kg} \cdot \mathrm{ha}^{-1}$ per centimeter precipitation gain in grass production with chemically top-killing a mesquite stand with $12 \%$ cover. Our model predicts $3.4 \mathrm{~kg} \cdot \mathrm{ha}^{-1}$ per centimeter of precipitation gain in grass production for their site. Heitschmidt and Dowhower (1991) report a reduction of net herbaceous production ranging from $1000 \mathrm{~kg} \cdot \mathrm{ha}{ }^{-1}$ to $1600 \mathrm{~kg} \cdot \mathrm{ha}^{-1}\left(\right.$ mean $\left.=1300 \mathrm{~kg} \cdot \mathrm{ha}^{-1}\right)$ with $80 \%$ mesquite cover in a 3 -yr study. In comparison, our study over $7 \mathrm{yr}$ had a range in reduction of herbaceous biomass of 600$1700 \mathrm{~kg} \cdot \mathrm{ha}^{-1}\left(\right.$ mean $\left.=1400 \mathrm{~kg} \cdot \mathrm{ha}^{-1}\right)$ with $100 \%$ mesquite cover.

Total and warm-season herbaceous production was higher on the silt loam than the clay loam soils, and each year the slope of the decline of total herbaceous biomass with increasing mesquite cover was almost identical on these two soils. However, total herbaceous biomass was not significantly different between the two soils in 1999 and 2000. This resulted from drought-related mortality of perennials from 1997 to the 2001. A decline in perennial basal cover from $\pm 6 \%$ to $\pm 1 \%$ took place over this period (Teague et al. 2004) due to successive dry summer and fall periods (Fig. 1). Similar results were found by Albertson and Weaver (1944) and Box (1967) in response to drought conditions. The effect of these successive dry warm seasons resulted in an additive effect from one year to the next with much lower biomass on both soils and reduced the difference in biomass between the plant communities growing on these soils in 1999 and 2000. The slopes of the regressions for each year in response to increasing mesquite cover differed with drier years having flatter slopes. Because warm-season plants normally provide most of the herbaceous biomass on either soil, the dry summers and variability in timing of precipitation changed both the slope and y-axis intercepts for the relation between soils each year.

In the absence of mesquite cover, warm-season herbaceous plants normally are more productive than cool-season herbs on either soil in this ecosystem. Warm-season plants were reduced about $75 \%$ under the highest levels of mesquite cover for any year on either soil. Mesquite is deciduous and grows in summer and is, therefore, more competitive with warm-season than with cool-season herbaceous plants. In addition, the number of dry summers (1996, 1998, 2000, 2001) and wet winters experienced over the experimental period had a major negative impact on warm-season plants. Ansley et al. (2004) report very similar results for clay loam soils at mesquite cover levels of $10 \%$ to $20 \%$ and $50 \%$ to $60 \%$ in a $3-y r$ study. However, they indicate a more precipitous warm-season decline at intermediate mesquite cover levels than in this study. Our data indicate a linear decrease in warm-season herbaceous biomass in response to mesquite cover increasing from $0 \%$ to $100 \%$. We speculate that this is probably because the current study had a greater number of data points at intermediate levels of mesquite cover $(20 \%$ to $50 \%)$ and more years of data collection, and because grazing was excluded in the Ansley et al. (2004) study. Dahl et al. (1978) and McDaniel et al. (1982) obtained results in the same range as this study at intermediate levels of mesquite cover following clearing mesquite of $30 \%$ and $25 \%$ cover, respectively.

Cool-season herbaceous biomass was not influenced much by increasing mesquite cover because much of the growth occurs when mesquite is dormant. Cool-season herbaceous response to mesquite was variable between years with silt loams having about 30\% increased herbaceous biomass under the highest levels of mesquite cover. The increase of cool-season herbaceous plants on silt loams under full mesquite cover would account for the more parallel decrease observed for total herbaceous plants on silt loam and clay loam soils with increasing mesquite cover. The slightly erratic response from year to year for total herbaceous plants was probably caused by cool-season plants showing little response to increasing mesquite cover as reported by Scifres et al. (1982) and Ansley et al. (2004). In addition, other factors such as declining biomass of competing grasses over the study period and changing seasonality of precipitation may have contributed to the erratic response. Increased cool-season herbaceous growth reduced the negative impacts of increased mesquite cover on total herbaceous production.

\section{MANAGEMENT IMPLICATIONS}

These findings have a number of management implications. The decrease in herbaceous biomass with increasing mesquite is one of the main reasons that ranch managers try to limit the abundance of this woody species. These data indicate an $\approx 50 \%$ reduction of total herbaceous biomass with $100 \%$ mesquite cover. Consequently, during a severe drought, woody plant competition can sharply reduce forage for livestock. The lower warm-season herbaceous biomass with increasing mesquite also increases the annual variability of herbaceous biomass and exacerbates the effects of summer drought. Although the decrease in warm-season herbaceous biomass is 
often partially offset by an increasing proportion of cool-season herbaceous plants, as we found in some of the years, this does not compensate for the reduction in warm-season herbaceous biomass (Scifres et al. 1982) and leaves significant forage deficits in the summer. This is due to a combination of a lower amount of forage as well as lower forage quality of cool-season grasses during the summer months in this ecosystem (Heitschmidt et al. 1989).

The parallel slope response of herbaceous biomass to increasing mesquite cover on the two soils suggests that there will be a similar increase in herbaceous biomass following woody plant removal. However, because silt loam soils are more productive, the response to mesquite removal will result in a greater economic benefit to clearing mesquite on silt loam than on clay loam soil (Teague et al. 2001). The silt loam soils produced $\approx 28 \%$ more herbaceous biomass than the clay loam soils, so for the same cost of treatment an increase in this amount of forage could be expected.

Cool-season forages are very important to ranchers because they provide high protein forage when warm-season forages are dormant and, therefore, reduce winter feed costs considerably (Teague et al. 2001). However, cool-season perennials are found in adequate quantities at very low mesquite cover if grazing levels are light or moderate (Heitschmidt et al. 1989), so there is no advantage for livestock production to increasing the proportion of cool-season perennials. Because cool-season perennial grasses are much less productive than warm-season grasses that they replace, there is no economic advantage to having mesquite cover greater than $15 \%$ to $20 \%$ as discussed by Heitschmidt et al. (1989). In addition, the response of warmseason grasses following mesquite removal treatments may be delayed for a few growing seasons, especially on degraded areas that have low presence of warm-season midgrasses (Ansley et al. 2004). Therefore, from a strictly herbaceous biomass perspective there is little advantage to having presence of mesquite. Although woody plant reduction has traditionally focused on enhancing herbaceous biomass for domestic livestock (Scifres and Hamilton 1993; Scholes and Archer 1997), conservation goals and income from wildlife are important and are increasingly becoming the primary management focus on many ranches (Bernardo et al. 1994; Rollins and Cearley 2004). Since many wildlife species require some level of woody plant cover, the data presented in this study will be useful for determining the consequences of managing for different levels of mesquite cover for both livestock and wildlife goals.

\section{ACKNOWLEDGMENTS}

The authors gratefully acknowledge the facilities and livestock made available by the W. T. Waggoner estate. We thank Rob Borchardt, Cody Bradley, Michel Bryant, Justin Clarey, Bob Cross, Diane Conover, David Echels, Joelyn Foy, Russell Fritsch, Tracy Gwaltney, Jason Hohlt, Eli Ornelas, Gerral Schulz, Riley Shoaf, Gina Spratt, Dustin Stacey, John Todd, Tim Tunnel, Dan Vasquez, and Jan Worrall for scientific and technical assistance. The project is also indebted to the competent inputs of the Waggoner Ranch staff, particularly Weldon Hawley, Dee Robinson, and Anne Pilcher. We also thank Drs Tim Fulbright, Urs Kreuter, and Sam Fuhlendorf for constructive criticism of earlier drafts and Dr Sara Duke of the US Department of Agriculture-Agricultural Research Service for statistical advice.

\section{LITERATURE CITED}

Albertson, F. W., and J. E. Weaver. 1944. Effects of drought, dust, and intensity of grazing on cover and yield of short-grass pastures. Ecological Monographs 14:1-29.

Andales, A. A., J. D. Derner, L. R. Ahuja, and R. H. Hart. 2006. Strategic and tactical prediction of forage production in northern mixed-grass prairie. Rangeland Ecology and Management 59:576-584.

Ansley, R. J., W. E. Pinchak, W. R. Teague, B. A. Kramp, D. L. Jones, and P. W. Jacoby. 2004. Long-term grass yields following chemical control of honey mesquite. Journal of Range Management 57:49-57.

Ansley, R. J., B. X. Wu, and B. A. Kramp. 2001. Long-term increases in mesquite canopy cover in north Texas. Journal of Range Management 54:171-176.

ARCHER, S. 1995. Herbivore mediation of grass-woody interactions. Tropical Grasslands 29:218-235.

Archer, S., T. W. Boutton, and K. A. Hibbard. 2001. Trees in grasslands: biogeochemical consequences of woody plant expansion. In: E. D. Schulze, S. Harrison, M. Heimann, E. Holland, J. Lloyd, I., and D. Schimel [EDS.]. Global biogeochemical cycles in the climate system. San Diego, CA, USA: Prentice. p. 115-138.

Bedunah, D. J., and R. E. Sosebee. 1984. Forage response of a mesquitebuffalograss community following range rehabilitation. Journal of Range Management 37:483-487.

BeLSKY, A. J. 1992. Effects of trees on nutritional quality of understory gramineous forage in tropical savannas. Tropical Grasslands 26:12-20.

Belsky, A. J., R. G. Amundson, J. M. Duxbury, S. J. Riha, A. R. Ali, and S. M. Mwonga. 1989. The effects of trees on their physical, chemical, and biological environments in a semi-arid savanna in Kenya. Journal of Applied Ecology 26:1005-1024.

Belsky, A. J., S. M. Mwonga, R. G. Amundson, J. M. Duxbury, and A. R. Alı. 1993. Comparative effects of isolated trees on their undercanopy environments in high- and low-rainfall savannas. Journal of Applied Ecology 30:143-155.

Bernardo, D. J., G. W. Boudreau, and T. C. Bidwell. 1994. Economic tradeoffs between livestock grazing and wildlife habitat: a ranch-level analysis. Wildlife Society Bulletin 22:393-402.

Box, T. W. 1967. Influence of drought and grazing on mortality of five west Texas grasses. Ecology 48:654-656

BRock, J., R. H. HAas, and J. C. Shaver. 1978. Zonation of herbaceous vegetation associated with honey mesquite in north central Texas. In: 1st International Rangeland Congress; August 1978; Denver, CO, USA. Denver, CO, USA: Society for Range Management. p. 187-189.

Canfield, R. H. 1941. Application of the line intercept method in sampling range vegetation. Journal of Forestry 39:388-394.

Cottam, G., and J. T. Curtis. 1956. The use of distance measures in phytosociological sampling. Ecology 37:451-460.

Dahl, B. E., R. E. Sosebee, J. P. Goen, and C. S. Brumley. 1978. Will mesquite control with 2, 4, 5-T enhance grass production? Journal of Range Management $31: 129-131$

Dahlgren, R. A., M. J. Singer, and X. Huang. 1997. Oak tree and grazing impacts on soil properties and nutrients in a California oak woodland. Biogeochemistry 39:45-64.

Diggs, G. M., B. L. Lipscomb, and R. J. O'Kennon. 1999. Illustrated flora of north central Texas. Fort Worth, TX, USA: Botanical Research Institute of Texas. $1623 \mathrm{p}$.

Dowhower, S. L., W. R. Teague, R. J. Ansley, and W. E. Pinchak. 2001. Dry-weightrank method assessment in heterogeneous communities. Journal of Range Management 54:71-76.

Dowhower, S. L., W. R. Teague, S. A. Gerrard, and D. M. Conover. 2007. Angle cover class: a variable plot technique for estimating shrub quantities in rangeland areas. Arid Land Research and Management 21:343-358.

Hamilton, W. T., and D. N. Ueckert. 2004. Rangeland woody plant and weed management-past, present, and future. In: W. T. Hamilton, A. McGinty, D. N. Ueckert, C. W. Hanselka, and M. R. Lee [EDS.]. Brush management: past, present and future. College Station, TX, USA: Texas A\&M University Press. $p$. 3-13. 
Heitschmidt, R. K., And S. L. Dowhower. 1991. Herbage response following control of honey mesquite within single tree lysimeters. Journal of Range Management 44:144-149.

Heitschmidt, R. K., S. L. Dowhower, W. E. Pinchak, and S. K. Canon. 1989. Effect of stocking rate on quantity and quality of available forage in a southern mixed grass prairie. Journal of Range Management 42:468-473.

Heitschmidt, R. K., D. L. Price, R. A. Gordon, and J. R. Frasure. 1982. Short duration grazing at the Texas Experimental Ranch: effects on aboveground net primary production and seasonal growth dynamics. Journal of Range Management 35:367-372.

Jones, R. M., and J. N. G. Hargraves. 1979. Improvements to the dry-weight-rank method for measuring botanical composition. Grass and Forage Science 34:181-189.

Knapp, A. K., AND M. D. Smith. 2001. Variation among biomes in temporal dynamics of aboveground primary production. Science 19:481-484.

Knopf, F. L. 1994. Avian assemblages on altered grasslands. Studies in Avian Biology 15:247-257.

Laxson, J. D., W. H. SCHACHT, AND M. K. Owens. 1997. Aboveground biomass yields at different densities of honey mesquite. Journal of Range Management 50:550-554.

Mannet.e, L.'T., And K. P. Haydock. 1963. The dry-weight rank method for botanical analysis of pasture. Journal of the British Grassland Society 18:268-275.

McDaniel, K. C., J. H. Brock, and R. H. Haas. 1982. Changes in vegetation and grazing capacity following honey mesquite control. Journal of Range Management 35:551-557.

McPherson, G. R., And H. A. Wright. 1990. Effects of cattle grazing and Juniperus pinchotii canopy cover on herb cover and production in western Texas. American Midland Naturalist 123:144-151.

Owens, M. K., R. B. Wallace, and S. R. Archer. 1995. Landscape and microsite influences on shrub recruitment in a disturbed semi-arid Quercus-Juniperus woodland. Oikos 74:493-502.

Peterson, G., G. R. Allen, and C. S. Holling. 1998. Ecological resilience, biodiversity and scale. Ecosystems 1:6-18.

Rollins, D., AND K. Cearley. 2004. Integrating wildlife concerns into brush management. In: W. T. Hamilton, A. McGinty, D. N. Ueckert, C. W. Hanselka, and M. R. Lee [EDS.]. Brush management: past, present and future. College Station, TX, USA: Texas A\&M University Press. p. 239-258.

Sala, 0. E., W. J. Parton, L. A. Joyce, and W. K. Lauenroth. 1988. Primary production of the central grassland region of the United States. Ecology 69:40-45.

SAS [computer program]. 2003. SAS/STAT Version 9.1 for Windows. Cary, NC, USA: SAS Institute Inc.

Schabenberger, O., and F. J. Pierce. 2001. Contemporary statistical models for the plant and soil sciences. New York, NY, USA: CRC Press. 738 p.
Scholes, R. J., And S. R. Archer. 1997. Tree-grass interactions in savannas. Annual Review of Ecology and Systematics 28:517-544.

Scifres, C. J., G. P. Durham, And J. L. Mutz. 1977. Range forage production and consumption following aerial spraying of mixed brush. Weed Science 25:48-54.

Scifres, C. J., and W. T. Hamilton. 1993. Prescribed burning for brushland management: the south Texas example. College Station, TX, USA: Texas A\&M University Press. 246 p.

Scifres, C. J., J. L. Mutz, R. E. Whitson, and D. L. Drawe. 1982. Interrelationships of Huisache canopy cover with range forage on the Coastal Prairie. Journal of Range Management 35:558-562.

Scifres, C. J., AND D. B. Polk, JR. 1974. Vegetation response following spraying of light infestation of honey mesquite. Journal of Range Management 27:462-465.

Teague, W. R., R. J. Ansley, U. P. Kreuter, W. E. Pinchak, and J. M. McGrann. 2001. Economics of managing mesquite in north Texas: a sensitivity analysis. Journal of Range Management 54:553-560.

Teague, W. R., S. L. Dowhower, and J. A. Waggoner. 2004. Drought and grazing patch dynamics under different grazing management. Journal of Arid Environments 58:97-117.

Teague, W. R., W. E. Grant, U. P. Kreuter, H. Diaz-Solis, S. Dube, M. M. Kothmann, W. E. Pinchak, and R. J. Ansley. 2008. An ecological economic simulation model for assessing fire and grazing management effects on mesquite rangelands in Texas. Ecological Economics 64:612-625.

uS Department of Agriculture Soll Conservation Service. 1969. Soil survey of Wilbarger County, Texas. National Cooperative Soil Survey. Fort Worth, TX, USA: US Department of Agriculture. $76 \mathrm{p}$.

Vantassell, C. W., And J. R. Conner. 1986. An economic analysis of brush control practices and grazing systems in the Rolling Plains of Texas, MP-1619. College Station, TX, USA: Texas Agricultural Experiment Station, Texas A\&M University.

Virginia, R. A., W. M. Jarrell, W. G. Whitford, and D. W. Freckman. 1992. Soil biota and soil properties in the surface rooting zone of mesquite (Prosopis glandulosa) in historical and recently desertified Chihuahuan desert habitats. Biology and Fertilility of Soils 14:90-98.

WalkeR, B. H. 1987. Determinants of tropical savannas. Oxford, United Kingdom: IRL Press Limited. $156 p$.

Warren, A., J. Holechek, and M. Cardenas. 1996. Honey mesquite influences on Chihuahuan desert vegetation. Journal of Range Management 49:46-52.

WEST, N. E. 1993. Biodiversity on rangelands. Journal of Range Management 46:2-13.

Westoby, M. B., B. Walker, and I. Noy-Meir. 1989. Opportunistic management for rangelands not at equilibrium. Journal of Range Management 42:266-274. 
Appendix 1. Species dominating each herbaceous functional group on the Waggoner Experimental Ranch, Wilbarger County, Texas. Species in each functional group are listed in order of abundance. Figures in parentheses indicate the number of species in that functional group encountered. Only species averaging $>1 \mathrm{~kg} \cdot \mathrm{ha}^{-1}$ are listed.

Warm-season midgrass (22)

Bouteloua curtipendula

Sporobolus compositus

Bothriochloa laguroides

Aristida longiseta

Eriochloa sericea

Tridens albescens

Hilaria mutica

Sporobolus cryptandrus

Sporobolus airoides

Panicum obtusum

Bracharia ciliatissima

Digitaria californica

Perennial cool-season midgrass (4)

Nassella leucotricha

Agropyron smithii

Poa arachnifera

Elymus canadensis

Annual cool-season grass (12)

Bromus japonicus

Hordeum pusillum

Perennial warm-season forbs (50)

Ambrosia psilostachya

Aster ericoides

Solanum elaeagnifolium

Artimisia Iudoviciana

Vernonia marginata

Teucrium laciniatum

Warm-season shortgrass (11)

Buchloe dactyloides

Bouteloua rigidiseta

Chloris verticillata

Bouteloua gracilis

Schedonnardus paniculatus

Panicum hallii

Warm-season tall grass (5)

Andropogon gerardii

Schizachyrium scoparium

Panicum virgatum

Sorghastrum nutans
Appendix 1. Continued.

Annual warm-season forbs (16)

Gutierrezia texana

Coniza canadensis

Gaura parvifolia

Iva angustifolia

Croton monanthogynus

Dracopis amplexicaulis

Helenium microcephalum

Xantium strumarium

Annual cool season forbs (36)

Plantago rhodosperma

Lepidium densiflorum

Gaura triangulata

Dacus pusillus

Centaurea americana

Gaillardia pulchella 